Article

\title{
Voicing and Visualizing Change: Perceptions of Environmental Heritage in the Baltic Sea Region
}

\author{
Savitri Jetoo * and Jaana Kouri
}

Citation: Jetoo, S.; Kouri, J. Voicing and Visualizing Change: Perceptions of Environmental Heritage in the Baltic Sea Region. Heritage 2021, 4, 1566-1589. https://doi.org/10.3390/ heritage 4030087

Academic Editor: Dmitry A. Ruban

Received: 28 June 2021

Accepted: 2 August 2021

Published: 3 August 2021

Publisher's Note: MDPI stays neutral with regard to jurisdictional claims in published maps and institutional affiliations.

Copyright: (c) 2021 by the authors. Licensee MDPI, Basel, Switzerland. This article is an open access article distributed under the terms and conditions of the Creative Commons Attribution (CC BY) license (https:// creativecommons.org/licenses/by/ $4.0 /)$.
Faculty of Social Sciences, Business and Economics, Åbo Akademi University, Tuomiokirkontori 3, 20500 Turku, Finland; jkouri@abo.fi

* Correspondence: sjetoo@abo.fi

\begin{abstract}
To address "wicked problems" that threaten the good ecological status of the Baltic Sea such as climate change with diverse stakeholder values and complex solutions, new interdisciplinary knowledge that incorporates citizen science is urgently needed. This paper scrutinizes environmental heritage in the Baltic Sea region by exploring what it means to persons living in the Baltic Sea environment. It asks the question, what is environmental heritage? It uses a qualitative research method using both texts and photographs - collected in an open competition-to consider humanistic viewpoints of persons living in the changing climate in the Baltic Sea Region. A thematic content analysis was utilized to identify emerging themes in the text and visual inquiry was used to decipher what meanings related to environmental change were conveyed in submitted the photographs. Some of the findings include that environmental heritage is perceived as experiences of living and interacting with the Sea and other non-human actors like animals, but also as material objects in the environment such as sustainable architecture. It also found that environmental heritage is articulated as a source of conflict, between users and uses and the traditional and new ways of life. Resolution of this conflict is important in guiding effective solutions to the challenge of climate change. It is thus important to develop interdisciplinary methods that facilitate the merging of different knowledge systems in order to generate effective solutions.
\end{abstract}

Keywords: Baltic Sea; wicked problems; climate change; public participation; interdisciplinary knowledge; citizen science; environmental heritage

\section{Introduction}

"What is Baltic Sea to me? Like a silver mirage calling us home, by the horizon lies The Baltic Sea. Like a clock with an infinite timeline, it never stops moving. Hidden in the dance of the waves there are silent whispers. Telling stories that they carry with them, from each place they have visited. You will hear them, if you'll stop for a minute and truly listen" (Respondent 0016).

The Baltic Sea (the Sea) is one of the largest brackish water bodies on earth and its surrounding coasts are home to 85 million inhabitants [1]. This large population is affected by and affects the Sea through activities such as fishing, agriculture, shipping, boating, land use modifications, and polluting. The consequences of these activities are wicked problems such as eutrophication and climate change; problems that are complex and subject to conflicting stakeholder values and perceptions on the root causes of the problem, and hence the solutions [2]. A collaboration of leading scientists found that the Baltic Sea is the world's fastest warming marine system and as such, can serve as a time machine to study future coastal perturbations [3]. Climate change effects in the Baltic Sea region includes increasing sea surface temperature by 1.35 degrees Celsius for the period 1982-2006 and sharper increases in air temperature than the global average since the 1870s [4]. There is much natural sciences literature on the changes to the Baltic Sea environment due to the changing climate, including the decline in the duration of the ice season and the ice thickness $[4,5]$. There is agreement that the predominant natural 
sciences focus of the literature on Baltic Sea is myopic and there is a need to include other disciplinary viewpoints [6-10].

Environmental change is human driven, and as such, the understanding of it would benefit from experience-based knowledge of people living in the environment and their perceptions of this change. Further, as climate change is linked to anthropogenic activity, it is also necessary to study it through humanistic lens such as cultural and environmental history, anthropology, and culture and art studies [11-13]. According to Burke [14], knowledge of environmental changes can benefit from studying the experiences of people in their environment during these changes, exploring their perceptions and adaptations. This is where citizen science plays a role and is the point of departure in this study of perceptions of environmental heritage in the Baltic Sea Region. This concept of environmental heritage as envisioned by the authors refers to the experiences and knowledge that persons perceive by living and recreating in the Baltic Sea region. This paper scrutinizes environmental heritage in the Baltic Sea region by exploring what it means to persons living and working in the Baltic Sea environment. It asks the question, what is environmental heritage? It considers humanistic viewpoints of persons living and working in the Baltic Sea Region. In so doing, it not only identifies relevant knowledge, but also facilitates the circulation of knowledge within and among actors in the region and beyond.

This article is based on a case study of the Living with the Baltic Sea in a changing Climate-Environmental heritage and the circulation of knowledge (SeaHer) - project of the Academy of Finland (2018-2022) [15]. In this project has practical and methodological objectives, which are closely linked to each other. One of the objectives is to identify, produce, and contribute to the recognition of the environmental heritage of the Baltic Sea, especially Finnish coastal and archipelago areas that are relevant to climate change adaptation. In crossing disciplinary boundaries, it seeks to bridge the wider divide between the academic sphere and the world beyond. In the process, the very understanding of the words, terms, and concepts that reside at the heart of academic endeavors is challenged. one key question of the project is what is meant by the words "the heritage" and "the environment." When these concepts are used together, does the new phrase describe more than these almost effete words as they are?

In this article key literature on environmental change and perception and on environmental heritage is first presented. It then describes the study area and the methodology used in the data collection. The results are then presented, followed by a discussion of the findings and finally, ending with concluding remarks.

\section{Conceptual Background}

\subsection{Environmental Change and Perceptions}

Since the mid-nineteenth century, in different parts of the world, conservation initiatives and environmental movements have been localized enterprises to protect particular places, ecosystems, or species that were under threat. The most far-reaching international treaty on environmental problems and sustainable development, the "Agenda 21" agreed at the Earth Summit in Rio de Janeiro in 1992, including a "Local Agenda 21" among its elements, to be forwarded by local covenant in partnership with civic society. This imitative connected with the assumption that people engaged with the environment most profoundly and effectively at the local level [11].

The Helsinki Commission's various datasets provide valuable information based on monitoring activities in the Baltic Sea Region [1]. For example, HELCOM PLC database stores data collected from pollution-load monitoring, such as waterborne nutrients and atmospheric nitrogen emissions. The biodiversity database contains information on macro species in the Baltic Sea, provided by the contracting parties from a single-entry point. The ten databases listed on HELCOM's website capture certain aspects of change at monitored points, but they do not document local experience of change in the environment. The literature has documented deviations between local experiences of change and climatic and weather data; the community had perceived climatic environmental change that affected 
their water supply, but this was not in the precipitation and temperature data collected [16]. The literature has documented perceptions of environmental change as useful in sustainability of resources as they are also able to capture socio-environmental issues and connections omitted by other methods [17,18]. Scientific ecological measurements provide useful information, but community perceptions are invaluable in guaranteeing that policy interventions are understood and accepted by the community [19].

The use of environmental perception as a valuable diagnostic tool can be traced to the United Nations Education, Scientific and Cultural Organization's Man and Biosphere program in 1968, where the study of environmental perception was recognized as a fundamental tool for the management of places and landscapes [20]. More recently, the Inter-governmental Panel on Climate Change [21] has specified that local knowledge should be used to inform climate adaptation planning; it defined local knowledge as placespecific knowledge of resident individuals. The IPCC [21] recognizes local knowledge as an entry point for climate adaptation as it balances past experiences with new coping measures. Perceptions of change can be especially useful in the review of small-scale regional environmental shifts because current scientific measures do not have the precision for a detailed and individual analysis $[18,22,23]$. While perceptions of environmental change can be deemed as subjective by quantitative researchers, they are important as they incorporate factors that are missed by other methods. The literature recognizes that perceptions of change may be influenced by the person's characteristics, but these characteristics also affect the person's life which matter in terms of policy action [24].

\section{Visual Perceptions of Environmental Change}

The environmental movement started out simply as the protection of the environment through policy measures to hold polluters accountable, which could be easily solved through the bureaucratic governmental approach. However, it is recognized that the wicked environmental changes such as climate change and eutrophication require solutions beyond the traditional approaches, with the need for public support and a shift in public awareness. There has been documentation in the literature on the challenges to engage the public on issues of environmental change $[25,26]$. For example, in a review of public perceptions of climate change in Europe and the USA based on 15 years of research, the recurring results showed that persons were aware of the issue of climate change, but their understanding was incomplete, and participants perceived it as distant in space and time [26]. Additional barriers to public engagement on environmental change include the uncertainties of climate science which deter effective communication to the public who may perceive climate change discourses as abstract and intangible [27]. Additionally, politics is an influencing factor, as political polarization and the absence of public and political discourse on climate change are major issues [27].

As such, efforts to deeply engage the public should use communication modes that would foster social learning, appeal to the values and beliefs of the public, and adjust to the changing environmental conditions [28-30]. Studies from the fields of risk perception and behavioral change pinpoint the significance of emotional engagement for stimulating public response to societal issues [31]. Academia, mass media, and non-governmental organizations have increasingly started to use visualizations of environmental change in a bid to connect these issues to the public in a meaningful manner. Environmental issues are being portrayed through visualizations as a tool to evoke them in a meaningful and personal way in everyday discourse and to lead to behavioral change [29,32]. Visual communication plays a crucial role in the interface between science and the public and is a critical contributor to the social and cultural aspects of environmental issues, but it is still underestimated [32,33]. Climate imagery is very useful to bridge the psychological distance that is advanced as one of the main hindrances against the perception of environmental change [34,35]. Images blend facts and emotion, engaging viewers as witnesses rather than detached receptors of information and claims [32] Further, images that are relatable to daily life are more effective in triggering pro-environmental behavior than cognition alone [30]. 


\subsection{Heritage and Change}

According to the Oxford Dictionary [36], the word heritage is defined as "the history, traditions, buildings and objects that a country or society has had for many years and that are considered an important part of its character".

With this definition in mind, the starting point for discussing the Baltic Sea as heritage or the environmental heritage of the persons living and working in the Baltic Sea Region is the recently released World Marine Heritage Report by UNESCO [37]. This report, officially released in 2021, recognizes 50 unique ocean places across 37 nations as demonstrating outstanding universal value (OUV) for possessing "exceptional marine biodiversity, singular ecosystems, unique geological processes or incomparable beauty" [37], p4. This list of 50 sites includes the High Coast/Kvarken archipelago, of the Baltic Sea. The High Coast is located in Sweden and the Kvarken Archipelago in Finland (Figure 1) on opposite sides of the Gulf of Bothnia, north Baltic Sea; this 346, 434 ha consist of the high islands, steep shores, smooth cliffs, and deep inlets of the High Coast contrasted with the thousands of low-lying islands, shallow bays, marine ridges, and boulder fields of the Kvarken Archipelago [38]. As shown on the map not to scale in Figure 1, Kwarken Archipelago has two zones and High Coast only one.

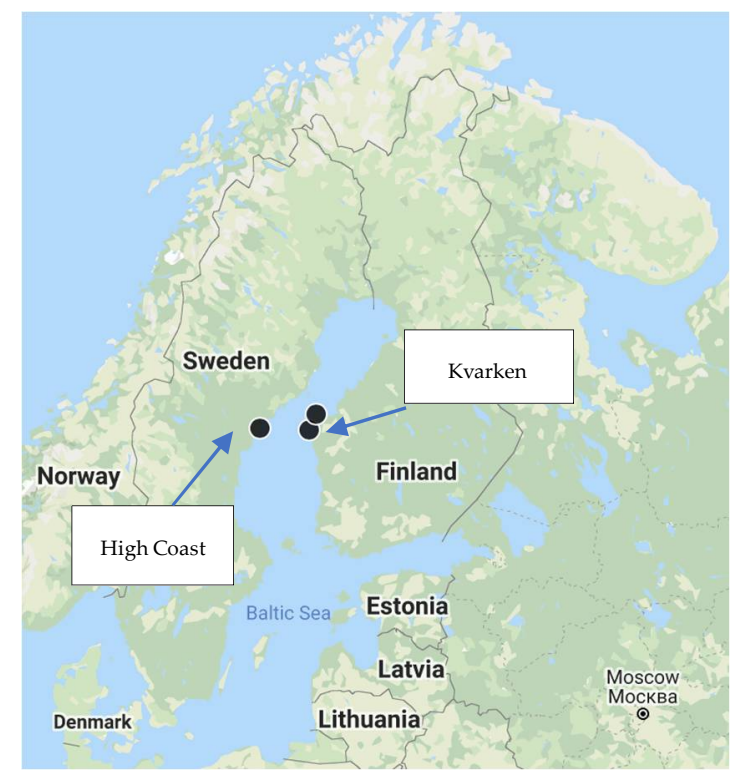

Figure 1. Location of High Coast/Kvarken Archipelago, UNESCO [38].

Archaeological findings point to 7000 years of human agrarian and maritime activities in the High Coast (HC). However, displacement of coastal settlements by the isostatic land uplift has led to a "relict" cultural landscape, with traces of different cultures at successive levels above the sea [38]. Today, there are 4500 persons in two settlements in the HC and 2500 persons in the Kvarken archipelago [38]. This report recognizes the knowledge inherent in these residents, saying that "adaptation of peoples to conditions created by land uplift means that geological history and cultural history are, thus, closely entwined" [38]. Although the report recognized the cultural heritage importance of 7000 years of human imprint living the world's highest isostatic uplift for future generations, it does not provide any information on the perceptions of change of residents living in this area. The governance of these heritage sites is at the local regional level, including representatives from municipalities and local stakeholders so there is a lot of local knowledge. There is also a transnational consultative body established at the regional level in Sweden and Finland for a joint management strategy. Although this article does not specifically target the residents in these areas, it is the starting point for dialogue on environmental heritage in the Baltic Sea region. 


\subsection{Heritage as Process and Disourse}

\subsubsection{Environmental Heritage}

The physicality of the conventional Western idea of heritage may the subject of national legislation and international agreements, conservations and charters. However, as Laurajane Smith ([39], p. 3; her italics) writes, "heritage is heritage because it is subjected to management and preservation/conservation process, not because it simply 'is.'" Heritage can be seen as a dynamic construct: it is constantly evolving, based on what people perceive to be meaningful in the past and present, worth preserving, or nurturing, for the future [40]. Heritage is about negotiation-about using the past, and collective or individual memories, to negotiate new ways of being and experiencing identity - and discourse, a form of social practice [39]. The concept of "heritage" refers to forms of action, modes of doing, and ways of being engaged in the world [41]. As a discourse, it not only organizes the way concepts like heritage are understood, but the way humans act, the social and technical practices they act out, and the way knowledge is constructed and reproduced [39].

In the official heritage discourse, heritage is classified as either cultural or natural heritage. The potential of the concept of cultural heritage lies in combining the tangible physical values with the intangible aesthetic, spiritual, and social values of heritages for the present and even for future [42,43]. Especially intangible cultural heritage represents the living actions, skills, and thoughts present in and between individuals. It is a form of activity that is both purposeful and unconscious of its end goal and that contains the power to change the world [44].

In the latter part of the twentieth century heritage became a highly active discourse, having been raised as a particular environmental and social concern during the 1960s and 1970s [39]. Cultural landscape, which is also a concept used on the UNESCO's World Heritage list, provides an example of the few encounters of the two domains: cultural and natural heritage. Cultural landscapes are increasingly understood in terms of a process, a place shaped by the interactions of people and nature over time [45]. Cultural landscapes can be seen as meeting grounds between nature and human beings, past and present, tangible and intangible values [46].

When the starting point is heritage as a process affected by living in close connection, not inside some nationally defined area, but with certain constantly changing environment, as in the case in and with the Baltic Sea in the SeaHer-project, where the concept of environmental heritage is used. It incorporates the tangible and intangible in the same process of heritage. It also combines the ideas of cultural heritage [47] and natural heritage, which is considered as the aggregate of the elements of biodiversity-flora, fauna, and ecosystems-and geological structures and formations [48].

"The environment" is one of the great political issues of our time and arguably the most pressing of current societal concerns [11]. "Environment" is only one of the myriad of ways that one can talk about the "natural world." It only became synonymous with that natural world during the twentieth century, and probably was only widely recognized as such during the 1960s [49]. The difference between landscape and environment is neither easy nor always necessary to make. As Paul Warde ([49], p. 42) well crystallizes, nature as a place for human self-discovery has been one of the most prominent narratives in western culture for well over two centuries: "The idea that we demonstrate our moral sense of purpose in our management of the environment is also well-established, although it has taken radically different forms, from seventeenth-century "improvement" to contemporary environmentalist ethics that seek to raise the status of non-human species to a level of greater parity with humans".

The human environmental relationship has several dimensions. It arises through experiences, consciousness, action, and observations, and this relationship lives in memories [50]. What things matter to man extends not only to personal experiences but also to the long-term mutual interaction between environment and man, the history of cultural meaning [51]. A key question in anthropological theories regarding the relationship between man and nature is who the agency is given to ([52], p. 153). The environment can 
be understood as encompassing both a material, natural and constructed and intangible environment, such as past environments or social relations, both with humans and nonhuman actors. In that way of understanding nature and man with cultural phenomena are not separate phenomena, but of the same entity.

\subsubsection{The Circulation of Knowledge}

The professional discourse that privileges expert values and knowledge about the past and its material manifestations also dominates and regulates heritage practices. However, alongside this professional discourse is also range of popular discourse and practices. Some of these may also be influenced by the professional discourse. It marks explicit way of negotiating social and cultural identity, value, and meaning [39].

In the SeaHer-project, the focus is on the circulation of different kind of knowledge, for example scientific, tacit, and experience-based knowledge $[14,53,54]$. By so doing, it aims to overcome the conventional dichotomy between naturally given and culturally constructed worlds. In anthropology, this dichotomy is commonly expressed by means of the contrast between the "etic" level of objective description and the "emic" level, in which cultural subjects make the environment meaningful. If the emic level is understood as reality constituted in relation to the beings whose environment it is, it is apparent that the world becomes a meaningful place for people through being lived in, rather than by having been constructed along the lines of some formal design ([52], p. 168, his italics). People in the present are not passive receivers or transmitters of heritage but active producers of it in their surroundings [55]. Environmental heritage mostly falls into the category of "heritage from below". It is a performance in which certain cultural and social meanings and values are identified, reaffirmed, or rejected and how they voice arguments and views that might be excluded from the official heritage discourses ([39,40], pp. 69-70). According to the sociologist Bruno Latour ([56], p. 114) they are the "matters of concern" of the research subjects which the researcher should primarily listen to.

The production of meaningful knowledge begins in the meaning-making situations, co-composed by human and non-human actors in a particular environment. With the concept of environmental heritage, the emphasis is on the nature of heritage as a product of co-creation formed by living with nature, that is, in close connection with the material world, including tangible changes that people experience in their surroundings. It enables to keep the perspective open for all possible actors, both humans and non-humans, in the process of meaning-making as a two-way communicative process [57]. Similar ideas are included in the Actor-Network-Theory (ANT) by Latour [56]. In ethnographic studies, listening to the voices of the field is considered good research practice, but it is important to highlight the voices of potential other non-human actors, those which the informants brought up in their submissions. In other words, what is central to such a view is an understanding of sociality and culture as a form of making, doing, and acting, through pragmatic, intentionality, and interaction between actors and non-human actors ([58], p. 4).

The SeaHer-project understands environmental heritage as a historical phenomenon. The meaning given to change is closely related to a sense of time, and hence it is related to the past and future. The concept of environmental heritage refers to the process of acquiring experience, knowledge, and skills that are constructed by living and acting in a particular environment with its non-human actors in a particular point of time. History is no longer as merely the history of people but living with other environmental actors, where also the non-human has its trajectories [59]. The ways in which human beings relate to their environment at particular points in time are often very specific to the local circumstances. Such cultural knowledge connects global environmental changes, such as climate change, with local changes, since this knowledge is constructed in connection with tangible changes in nature, including the prevalence of extreme climatic phenomena, changes in flora and fauna, and seasonal change. A history of environmental change is also a history of environmental futures [11]. 
Local cultural elements and identities can be seen as resources in many ways [44]. The SeaHer-project wanted to invite stakeholders and informants, especially the people living with and by the Baltic Sea, to the conceptual work. It sought to elucidate how society understands the concept of environmental heritage, and how it perceives change in and with the Baltic Sea. Hence, the project utilized a public competition for information gathering. This experimental case is relevant precisely from the viewpoint of the circulation of scientific and local knowledge, and in the issues that the informants themselves bring up.

\section{Materials and Methods}

\subsection{Data Collection and Analysis}

Ethnography has been described as catching moments by writing, moments that otherwise evaporate. Ethnographic inscription reveals networks of actors in those moments. [60,61]. In this case study, the ball is thrown to the people living in the shores of the Baltic Sea to catch the moments by photographing and writing. Participants were not asked to photo whatever concerning to the Baltic Sea, but to look it through the lenses of environmental heritage. They were given the task of the researcher in reverse order, to interpret a given concept, that is environmental heritage, by visualizing and writing the words.

This research is a qualitative study that explores the perceptions of change of inhabitants of the Baltic Sea Region. To gather data, participants were invited to submit a photograph and a 300-word essay on their relationship with the Baltic Sea. This study chose a narrative inquiry, in which stories describe human action [62], as the means to gather data; this invitation to submit was sent through the Baltic University Program, a consortium of Universities around the Baltic Sea region. It was also circulated on domestic and international email lists and social media, and printed out and advertised in the university environment in Finland. The target was reaching first and foremost the students, but the competition was open to everyone. Although due to the corona pandemic, the university corridors were very deserted at that time, it was still hoped that the competition would increase the routing of people outside on the Baltic Sea shores or in the memories associated with it.

Because the key concept of this research is environmental heritage as a historical phenomenon taking seriously the aspect of change from past to future, the announcement of the competition questioned: "What is it and whose heritage is it?" It was hoped that a possible participant "to answer this question, in the way she/they sees it through her/his camera and understand it with her/his own words, through her/his living experiences with the Baltic Sea. The advertisement instructed and at the same time attracted him/her to "Stay open to your ideas of all forms of actions and experiences, modes of doing and ways of being, or skills and knowledge related to coastal areas and archipelago of the Baltic Sea. Stay open to all possible actors, both humans and non-humans. Is it a living heritage or in danger of vanishing? Is it connected with changes in flora and fauna, in climatic phenomena or in seasonal change? Or something else? Tell us about your relationship with the Baltic Sea through your photo for a chance to win this state-of-the-art iPad!"

At the beginning of March 2020, announcement was circulated again. A new poster was made for it, and the text of the announcement was edited a bit, too. At the beginning of the text, there was more strongly the idea of the changes in the Baltic Sea: "Do you live or recreate in the Baltic Sea Region? Is the Baltic Sea changing and has this affected your activities in relation to the Sea? Answer these questions in the way you see it through your camera and understand it with your own words, through your living experiences with the Baltic Sea."

The aim to organize a bottom-up research was to get data about the ideas, thoughts and performances of the entries about environmental heritage themselves. This was also done to have an experiment, to test and make the concept work of "environmental heritage" visible in the process of the circulation of knowledge. The design for this study was 
intentional, with a qualitative design chosen so as to obtain a context specific performance of the environmental heritage in the Baltic Sea Region.

Through this call, a total of 23 texts and photographs were received. The ethicality of the study was ensured by the anonymization of the authors, encoding the writings as soon as they were reached. When the results of the contest were announced, no identity of the authors was revealed in an announcement in the project's website. Writings and photographs were encoded with numbers: submission 001-0023. Each number referred so to writing and a photo (e.g., Respondent 001). The texts were stored in a word document and the photographs in a pdf document. A thematic content analysis was conducted. Visual analysis was conducted on the photographs. The study then went on to use narrative analysis, which is the analysis of natural language to construct an understanding of the meanings given to individual experiences through emergent themes [62]. Each line of the submitted text, or transcript, was analyzed to develop themes in an inductive process, with highlighters used to underscore statements related to knowledge and skills and environmental change in relation to the sea. Sections of the texts that were very descriptive or inferential and were labelled with codes iteratively, as these initial codes were converted to broader themes based on similar underlying concepts [63].

Research rigor was preserved throughout the study, from the design of the study, the maintenance of reflexive journals, the collection and analysis of the data, and the interpretation of the findings [64]. However, this study also recognizes that a limitation is transferability of findings as the sampling of participants was specific to academic environments. This does the not limit the usefulness of the findings to the particular purpose, i.e., to contribute and start dialogue on the relationship of people and environmental change and more broadly, the new concept of environmental heritage.

\subsection{Visual Data Analysis}

Visual data refer to photography, graphic representations, and video, with photography requiring more interpretation than the other data sources [65] Visual data and analysis are part of qualitative research as they relate to actors' interpretation of the data and address cultural meaning of visual data [65]. Photographs can be seen as a visual cultural representation of reality through certain visibilities, also producing the visibility of an object by its absence [66]. Moreover, the fact that you decide to take e.g., an aesthetic image is part of the cultural heritage, and photographing nature is part of the experiencing the sea and the relationship with the sea (transcription of focus group (TFG)). As such, it is performing the heritage. The objects included and excluded in images are important factors in meaning-making and the construction of the particular reality; images are socially constructed, reflecting the identity of the creator [67]. Photography offers multi-layered meanings through its intentional and subjective representation, allowing recipients to perceive them in different ways but the divided understanding of the photograph is diminished if the photographer and recipients share common socio-cultural practices [66]. For the social sciences, "pictures provide us with personal insights as well as with a personal record of spatial and social relationships" ([65], p. 4).

This research used submitted photographs from the general public as a supplement to the submitted text as data. Twenty-three photographs were obtained and analyzed. Here photograph is understood as a means of depicting visual characteristics of the Baltic Sea environment. These photographs were taken with some form of a camera and submitted electronically. There are numerous ways to analyze visual data, but this paper uses the qualitative approach to address the cultural meaning of the photographs and the ways in which the participants themselves perceive the data. Visual data should provide compelling narratives that encourage the audience to interact with the information [68]. According to the literature [68-71] vivid and compelling images that evoke an emotive response from viewers have the following attributes: 
i Realism-realistic (experiential), photo-realistic, or "lifelike" imagery creates experiential qualities and makes abstract concepts "concrete." Realism can also lead to more robust knowledge construction.

ii Resonance-personally relevant environments (i.e., iconic, well-known landscape symbols) to which people can relate, such as local and recognizable neighborhoods. Familiar landscapes tend to be associated with more positive affective response [72].

iii Immediacy-images that display short-term conditions or possibly longer-term conditions to appear nearer term through speeding up time.

iv Inspiring and Intuitive-images that contain images of people, animals, or other symbols with strong affective content.

$\mathrm{v}$ Demonstrating future consequences-displaying actions or inactions and posing "what if" questions for alternative futures.

This research takes into consideration these factors as well as the pictures' context and the ways of connection to the text. Thus, it is taken a step beyond just perceiving the objects in the picture to deciphering the links and relationships to other elements and layers both present and absent from the photographs. It takes cognizance of the literature which finds that enhancing emotions through climate communication may be a useful tool for engaging audiences on the issue of climate change [73].

\section{Results}

\subsection{Perceptions of Environmental Heritage}

The definition of heritage was explored directly by asking persons what the term means to them and indirectly by asking such questions as "whose heritage is it" and "tell us about your relationship with the Baltic Sea" and "stay open to experiences." One writer pondered the nature of heritage, by writing, that "Heritage can be material, such as the continuation of biodiversity, or intangible, such as the story of the little mermaid in Andersen's writings. (Respondent 0018). Another notes that "So this environmental heritage related to the Baltic Sea is our common heritage, it's our way of living, it's our way of thinking, it's the way we're designing things and taking care about them" (Respondent 0022).

This definition also captures the idea that heritage includes experiences, but also the objects in our environment and sustainable architecture. This idea was also echoed by respondent 009, who said that environmental heritage is "cultural, historical and natural". Environmental heritage is also viewed as operating as a connector of the community, as articulated by one participant: "A meeting ground for different interests but also a gathering point for mutual experiences, the Baltic Sea forms the basis for the environmental heritage of many, and for more to come ....... As such, the Baltic Sea forms a living environmental heritageconstantly reforming; ever rebuilding — and always in need of collaboration between the actors" (Respondent 0013).

There is also the articulation of the economic usefulness of heritage as resources that are diminishing, and exploited by humans, "the resources provided by this environmental heritage are diminishing, and this process is just footprints, footprints of people who do not care, who live in illusions. There is only one answer: the Baltic Sea is an environmental heritage, a heritage of our land, not a human heritage. Mankind acquires this heritage, and does not appreciate, of course, not all, many try, like us" (Respondent 0021). This economic consideration was also articulated by the respondent that linked architecture with heritage: "By destroying the Baltic Sea ecosystem, we lose a large part of our acquired cultural heritage, significantly reduce economic benefits, as well as permanently interfere with natural processes, so we will do the opposite, improve our nature, our Baltic Sea, our Heritage of nature and land" (Respondent 0021). Another notes that, "Our architecture projects should be related with environmental heritage of particular place such as Baltic Sea Region" (Respondent 0022).

There is also the synonymous use of environmental heritage with cultural heritage, with some respondents referring to the former by the latter. For example: "By destroying the Baltic Sea ecosystem, we lose a large part of our acquired cultural heritage, significantly reduce economic benefits, as well as permanently interfere with natural processes, so we will do the opposite, 
improve our nature, our Baltic Sea, our Heritage of nature and land" (Respondent 0021), and "The Baltic Sea has turned out to be a considerable part of my cultural heritage, moreover a legacy of mine" (Respondent 0014).

This concept of cultural heritage is also linked to the idea of environmental heritage as a place, a location, "Torngrund in a blanket of ice, we long for the day that we once again can get a glimpse of the odd building. It has become a cultural heritage" (Respondent 0023). As said, the texts can be seen all as performances of this theme. Some of the texts referring to location had heritage mentioned directly, such as: "The ecological heritage of the Baltic Sea is an integral part of North-eastern Europe" (Respondent 0012). There was also articulation of the idea that heritage is linked to fauna, the equating of environmental heritage with ecological heritage: "One of the most important elements of the ecological heritage of the Baltic Sea is its fauna" (Respondent 007)

Heritage is also articulated as a source of conflict, between users and uses and the traditional and new ways of life. One of the respondents 0014 also titled his/her text as "The Baltic Sea and its Environmental Inheritors" and wrote that "A spring of life, but as such, a contest ground for life, where flora has suppressed fauna by means of algae blooming, where wind turbines have conquered the free space of plumed aviators, where submarines are said to be spotted and where the wildlife stands at the risk of being tamed. The Baltic Sea forms a contested field where one's heritage is affected by another's innovation, where one's customs are challenged by another's novelties" (Respondent 0013). By writing this, the author referred to the actors and agencies of both human and non-human actors.

Visual Representation of Environmental Heritage

Visual data represent the intangible, nonverbal, and tacit environmental heritage, and in the competition the texts and photos complemented each other, and together performed the environmental heritage, as the participants understood it. In keeping with the practices in the literature for visual data analysis [68-71], this research relied on third part interpretation of the narratives of environmental heritage presented in the photos by the respondents. In this case, since this is an explorative study, this article will present the interpretations of two of the photos by a panel of four. This is taken from information already presented on the SeaHer [15] website blog.

The photo from respondent in Figure 2 was interpreted in their own words to convey environmental heritage in all the ways described above, including a sense of place, cultural heritage, incorporating the economic aspects, and becoming worried about the pollution and its impact for future generations. This photo was interpreted as a visual representation of heritage by the focus group of four persons as:

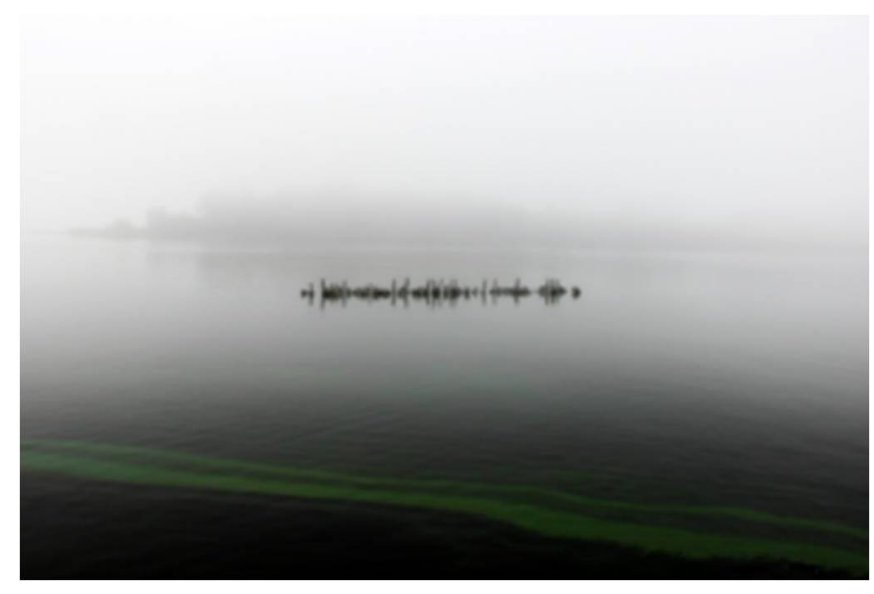

Figure 2. Environmental heritage as "misty future with algae" (Respondent 0019).

"... The image depicts the environmental history of the Baltic Sea, e. g. pollution and awareness that there are a lot of dumped /forgotten things under water. It is a problem 
man have to solve before reaching the possible future. The island that is obscured by the mist gives a sense of mystery and not knowing what the future holds. At the same time, it is as if the time is stopped, stagnated, in the photo... . The green mass of the algae leads the observer nicely into the picture and the wooden structure and its reflection looks like a soundwave, a message perhaps?...."

Here environmental heritage is interpreted in terms of the history of past and forgotten things that need to be resolved before going into the future. It is also represented as a mystery, a message that is subject to interpretation of the observer.

In this second example of visual representation of environmental heritage, the photographer represents environmental heritage as a location where trash collects, not only from near but also from afar (Figure 3). The respondent highlights the interconnectedness through talking about trash seen in local places but originating from other places in the world. The interpretation of the focus group, of this visual representation of the photo, is captured in these few words from the blog on the SeaHer [15] website blog:

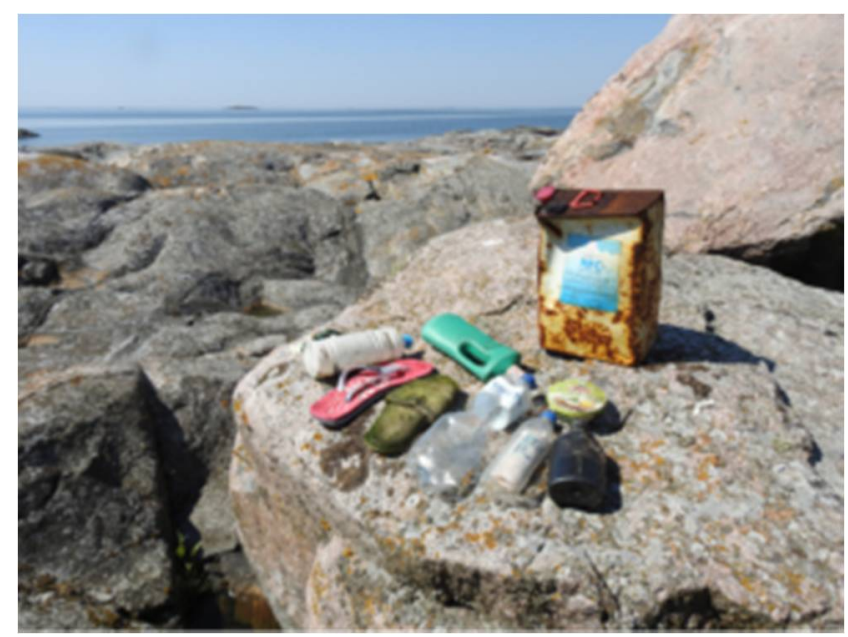

Figure 3. Environmental heritage as "rubbish at the shore" (Respondent 0017).

"The story and image tell about the personal relationship with the sea ... It is the cultural heritage of the modern era that we are transmitting into the future. The picture also hints at the future, as it raises the concrete question of what happens next to the garbage. One of the bottles seems to contain a letter. It's a message from the past to the future, hopefully full of hope ... . There is a looming of an island on the horizon, or as a mirror image of the island on the front, and that could be thought of as symbolizing the unknown, hopefully cleaner and fresher future, even the future now seems to be blurry."

Here again the views of the focus group echo those coming out from the texts of the respondents. It is likely that because of common cultural heritage that the interpretation of environmental heritage is similar. Here, environmental heritage is seen as emanating from the personal relationship with the sea, and also the intergenerational aspect is strongly emphasized. There is also the question of an unknown future, as the relationship of persons with the Sea in the future is not known, whether it will be responsible stewardship or a continuation of pollution that destroys the ecosystem.

The images entering the competition could be divided into a continuum with aesthetic, sentimental, and intuitive (see Section 3.2: ii, iv) at one end and documentary or everyday depictions (see Section 3.2: i, iii and iv) at the other extreme. The styles, however, were head-on in pictures and texts, and did not exclude each other. For example, a picture might be a representation of your own experience (ii and iii) from the moment you were in that picture. Likewise, for example, the picture (F0013) (Figure 4) of wind farms at sunset (see Section 3.2: i, ii) is accompanied by a narrative of heritage from the past and the future (see Section 3.2: v). The image can also be interpreted in many ways by the viewer (TFG). 


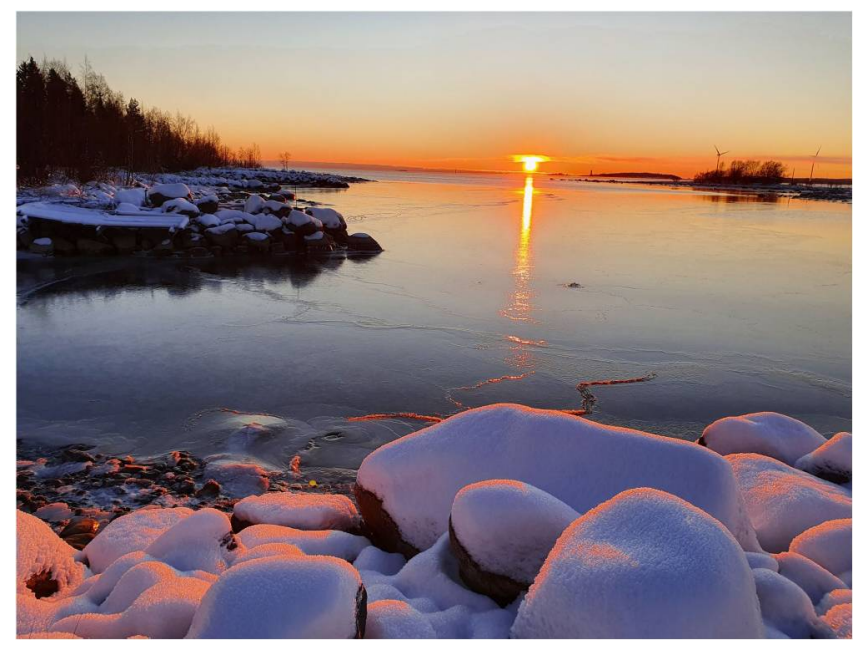

Figure 4. Environmental Heritage from past and future: windfarms at sunset (F0013).

For example, you can see an image as a representation of the tradition of representing landscape, such as, for example, in Figure 5 (F0012). One of the focus group members saw it as a pastiche of Caspar David Friedrich's painting, "Wanderer Above the Sea of Fog" and a piece of the tradition of depicting romantic scenery. On the other hand, in the picture the man was seen small in the face of the greatness of nature and the change brought by spring, when in Friedrich's painting the man is presented as the ruler of nature (TFG).

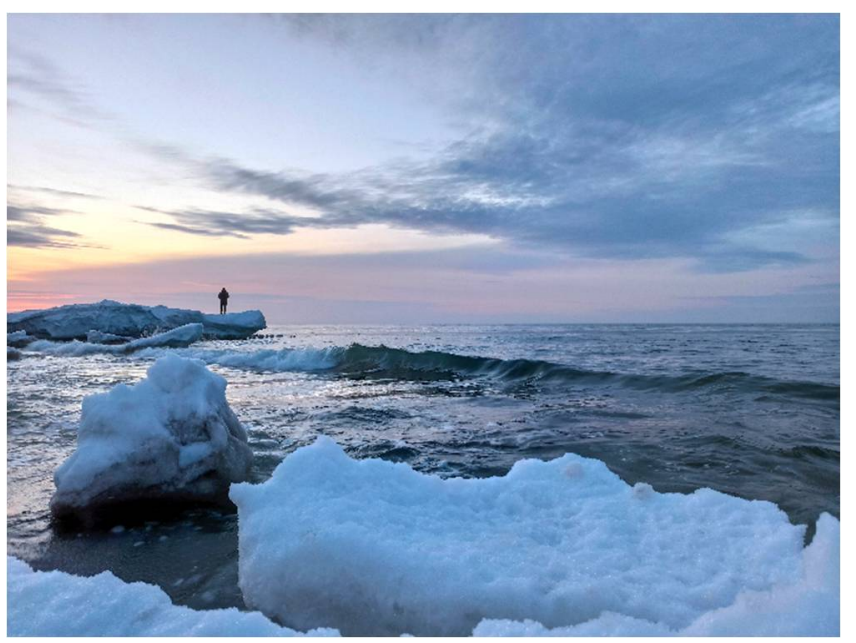

Figure 5. Environmental Heritage as reflections on the "majestic beauty of nature" (F0012).

\subsection{Environmental Heritage and Agency and Activities}

The actor-concept was mentioned in some of the texts, as previously noted. Writings can be analyzed also according to which actors the author had included in her/his text: actors included the Baltic Sea, the author her/himself, states and countries, or non-human actors such as objects, buildings, or animals and plants.

What comes to the agency of the author him/herself, some of the texts were factual texts in which the author was an outsider in the role of observer. The other extremity was a text in which the author saw or perceived the Baltic Sea as a functional entity, an ecosystem, of several organisms, as already above quoted author of the text-Respondent 0013 wrote, that: "an ecosystem comprising the livelihoods of the walking, the swimming, and the flying - where the bird caught the fish and the hunter the bird".

The authors' own role will emerge as a description or list of various activities, or as an active participant in acting for the Baltic Sea. The activities mentioned or described in the writings were diverse. Some of the authors described both physical activities such as: 
"to swim," "to jump," "to row" and more abstracts or mental activities like "to explore," "to connect" (Respondent 001). Some described the activities at the sea level or under it, such as the winter activities on the ice, like: "skiing, ice-skating, having picnics, and fishing with nets under the ice" (Respondent 003), or "take off shoes and go with tripod and camera into the water" (Respondent 008).

One participant recalled how she sat on a rubber boat during childhood (Respondent 0014) (Figure 6) and another "having cruise trips along the sea and watching the view from the top of the ship" (Respondent 005). Memories also included descriptions how, for example, one has observed the sea by, "laying on the quay and looking down through the clean water to the bottom of the sea" (Respondent 0015).

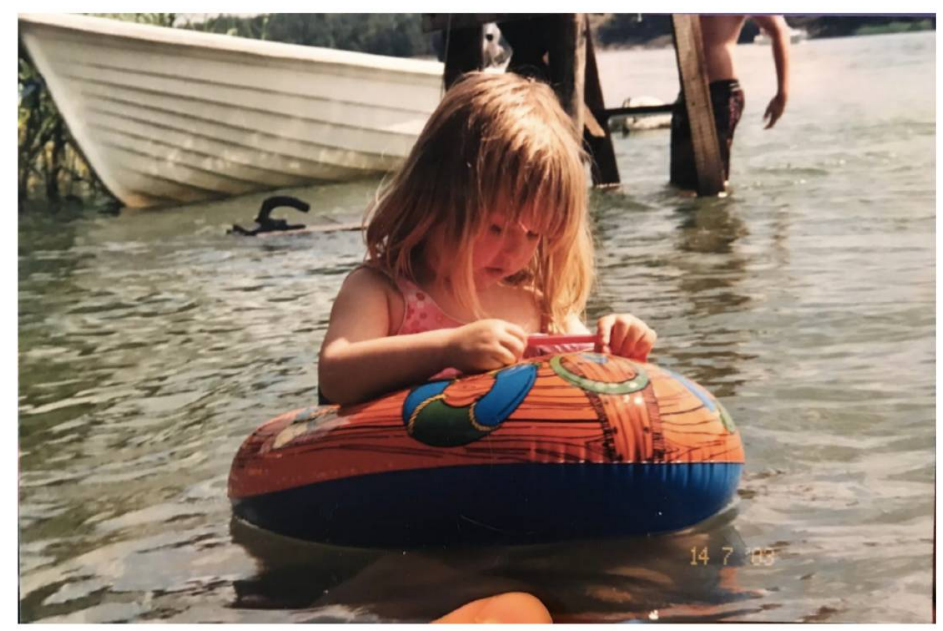

Figure 6. Environmental Heritage as time spent in the sea: View from a rubber dingy (F0014).

One writer summed up the multisensory experience included in several texts, "to enjoy the environment and what it provides, to watch the endless sunrises and sunsets, to listen to the sea and its rustles, to feel how water surrounds you in its magic" (Respondent 0021). In some of the writings the idea of excessive human activity was present, as in the following quote:

"We're so busy running that we don't notice what gifts it [the Baltic Sea] is giving us and neither what we are leaving behind as we go. We use its resources, but in the hurry forget to be thankful and we leave a great deal of a mess behind" (Respondent 0016).

The idea of "taking care about the Baltic Sea" (Respondent 0021) was expressed in different ways, such as, "it is our duty to protect this environmental heritage, because it is something what we should save for next generations - it's birds, fishes, architecture, forests and so on" (Respondent 0022), Or as a description of the already initiated activities to clean up the environment, from, "just kicking plastic bottles lying on the strands" to "collecting trash" and starting "an Instagram account with photos on plastic items" (Respondent 0017).

In about half of the writings the descriptions either included or considered other than human actors. There were many actors, such plastic boats, built boats or a beacon, organisms (e.g., Respondents 0018 and 0019), examples from flora and fauna, or islands. Some were mentioned with their biological group names, such as forest pathogens and bladder wrack (Respondent 0011), or by specific epithet, such as Mytilus edulis and Cerastodermas (Respondent 0014). One participator of the competition has sent a picture and text about seabirds, in which he/she wanted to stress that, "The Baltic is much more than just a beautiful view and a nice beach - it is also home to millions of living creatures that depend on you and me" (Respondent 007). Moreover, actants, that are both tangible and intangible actors, depending on the meaning they have in text, were mentioned such as "COVID-19" (Respondent 0020) and "restless heart" (Respondent 0018). In fact, one can think that when writings are performances of environmental heritage, the actors are all both intangible and tangible. 
In some writings the Baltic Sea or sea itself was understood as an actor. It came up in the following expressions, for example: "The Baltic Sea is tempting. It is sending you an invitation by this picture" (Respondent 001). In these descriptions, the reciprocity of the man and the sea, the conversation, also comes to light. The submission Respondent 002 was a poem about the dialogue, with the topic "The Sea and Me," and in which: "the sea speaks in a deep voice to my sad soul." In that poem the sea is experienced to answering "fatherly" and calmingly to the writer. For one of the writers:

"the Baltic Sea is something that gives me inner peace and well-being. The archipelago is the place for me to unwind, forget hurry worries and connect with nature. I couldn't imagine living somewhere with no shores. The Baltic Sea is a re-source for human beings, both concretely and mentally, and also something we must protect" (Respondent 0015).

Furthermore, in some other writings, the agency Baltic Sea was very diverse, having at the same time physically and mentally agency, which are inseparable (look also Respondent 0020), like the writer of the following quotation ponders, "The sea connects the islands and provides the possibility for the migration of organisms. The sea is also quiet, it is tolerant, and inclusive of all rivers, it also soothes my restless heart every time I stand close... The sea is not alone, it has everything, it is the origin of all life. The sea is wild and gentle, tolerant and ferocious, full of vitality and fragile" (Respondent 0018). In another writing the Baltic Sea is seen as an area, and a place, "as an aquatic bridge between the Nordic region and Continental Europe for centuries" and "a place of bountiful resources" and "a meeting ground," "an ecosystem" and "a breathing landscape," which "provides a home for many" (Respondent 0013).

Moreover, the third writer stresses the role of the Baltic Sea as "a place where to find themselves (future generations) when they get a little bit lost" (Respondent 0016). The last three writers point out how the idea of "environment" is always particular, localized perspective that shapes opinion and action, and the question of how humans locate that sense of locality with the knowledge that it has value according to its situation in the shifting dynamics of global processes. [11], p7, their italics. This locality, which is also a historical phenomenon, as environmental heritage is too, is well itemized in the following writing, "So this environmental heritage related to the Baltic Sea is our common heritage, it's our way of living, it's our way of thinking, it's the way we're designing things and taking care about them. As far as we still have a chance we have to take care about Baltic Sea because it's our source of food, energy and it's witness of our history" (Respondent 0022).

\subsection{Visual and Articulated Perceptions of Environmental Change}

It too varied how the respondents viewed change. In one of the texts, the change was mentioned as all-encompassing change, "We live in a time of extremely rapid change, whether it is technology, mobility, global markets, or politics. While much of these are positive the fast pace of life is having an increasingly negative impact on us humans, the animals we share this planet with and of course the environment. We are both actively perpetrators and victims of the destructions, part of global climate changes we as individuals aren't always sure how to stop" (Respondent 004.)

In other writings, the content was based on environmental science perspective, "Environmental problem of Baltic Sea region is one individual change in the natural environment or a chain of ecological impacts which is seen harmful relative to the environment, human or society of Archipelago and Baltic region" (Respondent 006). Another notes, "The constantly increasing amount of garbage produced by all of us can change and is already significantly changing the ecology of entire regions" (Respondent 007). This was extrapolated further by honing in on the fauna, both in photo (Figure 7) and in the text: "Over the years, the number of seabirds on the coast has been decreasing, but steadily increasing in cities that are further from the sea" (Respondent 007). 


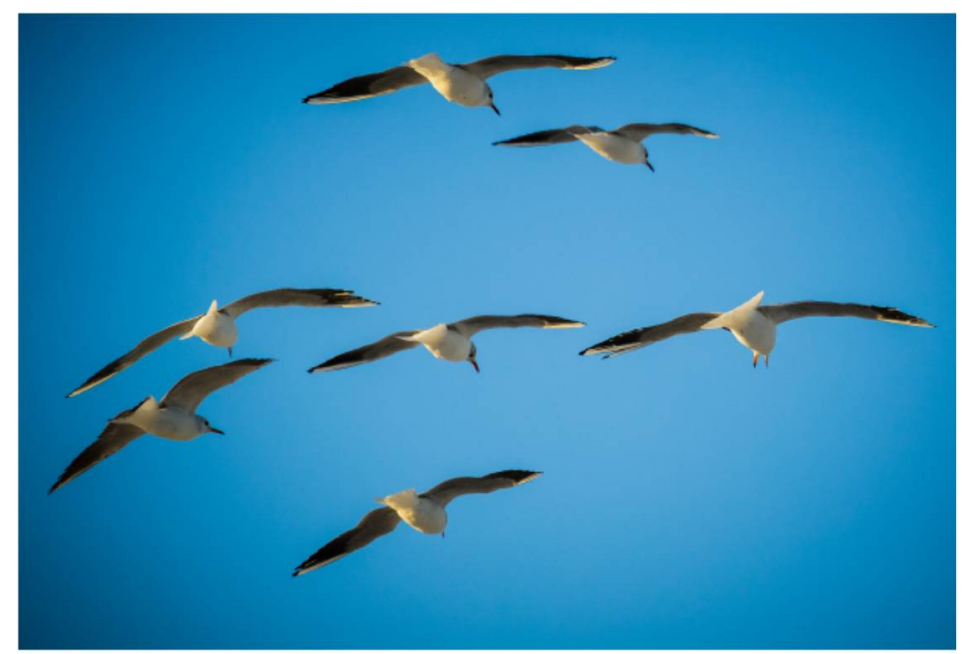

Figure 7. Visual performance of environmental change: Fluctuating numbers of seabirds (Respondent 007).

In some other texts, the change came up in a way of describing something through expressions of time, like in the picture and text of Respondent 0023 (Figure 8), where there are old and new buildings (a beacon and a pipe of a coal power station) in the same landscape (look also Respondent 0010 text and photo). The old beacon and the coal power station are kind of the same shape though they have been used for very different purposes. Because of their size, they're both very visible from the sea. The picture and text also included the idea of negotiation and choice of heritage: what kind of heritage present generations want to transmit to the future? (TFG).

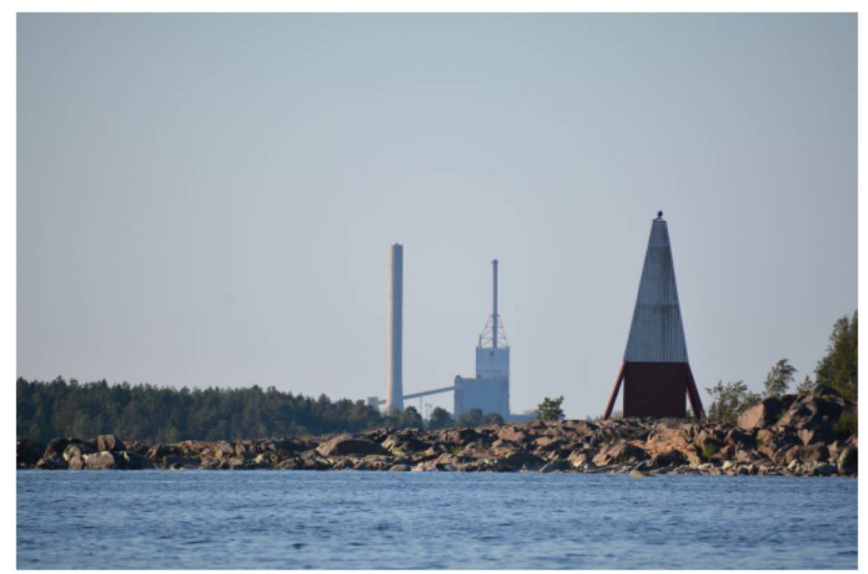

Figure 8. Visual performance of environmental change: The Härkmeri beacon (Sockertoppen) (Respondent 0023).

The historical aspect could also interpreted to be the basic idea of the narrative by presenting things in the way they used to be and how they are now (e.g., Respondents 0011 and 002). Several photographs and writings were filled with nostalgia. One of the photographs (Figure 9 was a very traditional representation of cultural heritage. It was taken from an old fish hut with a fisherman clearing his fishing net. The image also raised the importance of environmental heritage as know-how, cleaning nets. Beside of it, the photo showed many (material) details from inside the hut. Anyway, the picture did not involve future perspective, time had stopped to the spot. 


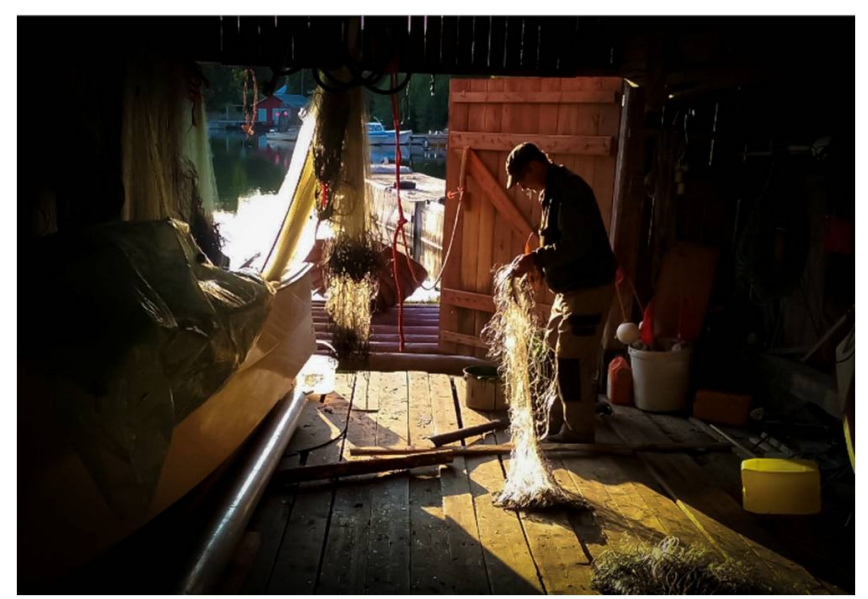

Figure 9. Environmental heritage as traditions: the sea decides (F0010).

One of the images was a picture (Respondent 0014; Figure 6) of the author's childhood. In the photo, she sits on a Moomin -rubber boat and looks into the water. The picture is clearly personal (see chapter 3.2: iv). In the text, the author wove together his bloodheritage as well as his/her fate to become a researcher of the sea. In the writings, the nostalgia kind of feeling is presented as, "feeling the connection with home," "a connection to something stable," and realizing that "we are too late" (Respondent 004).

However, the nostalgia embodied in longing need not only be about admiring or reminiscing something that has stopped in the past but transferring something from the past to the future by performing it in the present [51,74]. As a continuum in the writings, one could see opposition to change, that is, admiration for stability, and as another extreme there is the idea of the possibilities that change contains, "Not all change is bad. Yes, the reports regarding the Baltic Sea paints a bleak picture of its future state, but small things like the bladder wrack, gives me hope" (Respondent 0011).

The change in the current situation should be influenced, in the opinion of the authors, either by organizations in the states (Respondent 0012) $\mathrm{r}$ by individual choices, such as in choosing: "the right profession where I can work for a better Baltic Sea, which future generations can enjoy as much as me and my great grandmother has" (Respondent 0014). Or by change of the attitude toward our own actions "just need to think about the future and to look behind for the footprints we leave in the sand" (Respondent 0016). One writer sees that the, "only one answer" to this too rapid change of "the ecological balance in the Baltic Sea" is that "Baltic Sea is an environmental heritage," which we should "appreciate": "to gather behind us, take care, enjoy everything the Baltic Sea gives us, take a breath and close our eyes... it is her, we will love and respect it so that the sunrises and sunsets doesn't end' (Respondent 0021)

The quote showed active inclusion in achieving positive change. How a person perceives oneself to be placed in relationship to the Baltic Sea entity affects his or her own activity about participating in change (Figure 10). 


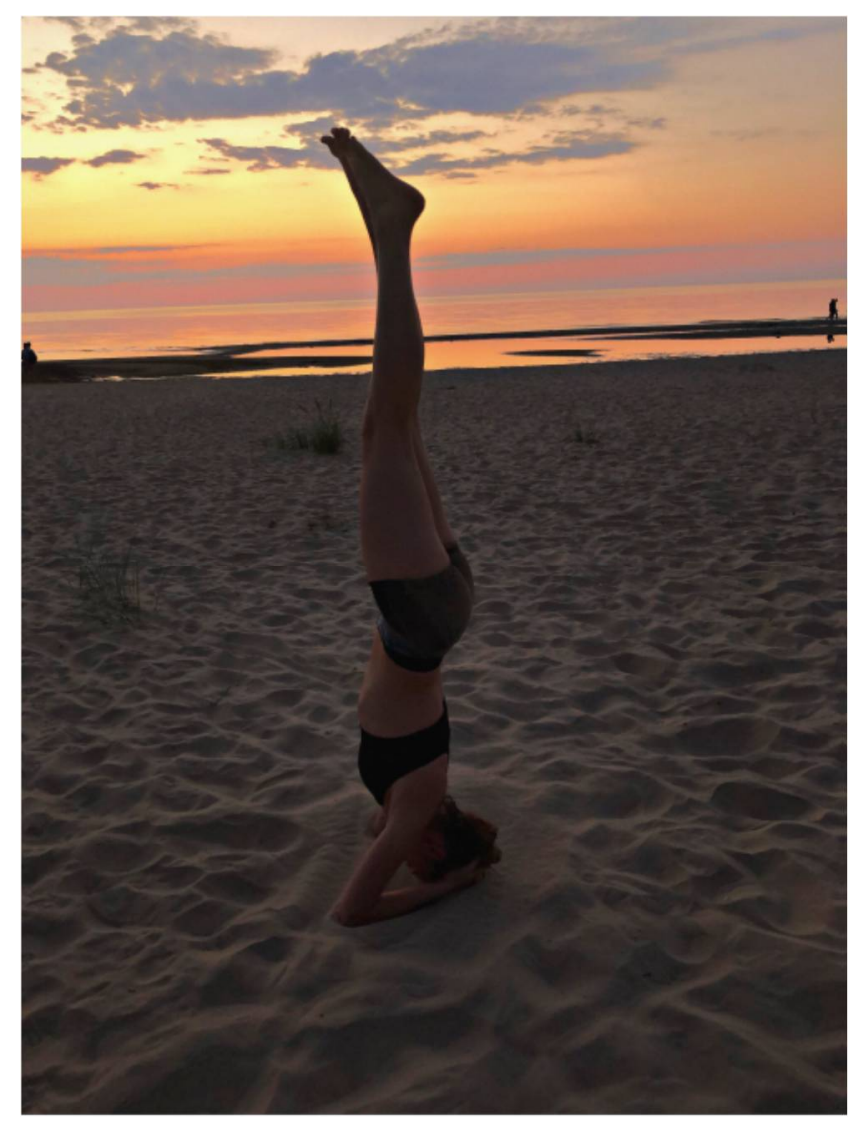

Figure 10. Visual performance of change and the hope for the same: Endless sunrises and sunsets and human action in balance (Respondent 0021).

The photographs texts can also be seen as performances of the author's relationship with the Baltic Sea or environmental heritage as such. The relationship was expressed to be a conversation (Respondents 002 and 0016); a dependence, like in text Respondent 009, "The nature is not dependent on us, but we depend on it"; a part of one's life (Respondent 0011).

Or realizing that Baltic Sea is one's home (Respondent 0012); a place, where one finds her/his personal history and roots (Respondent 0014); connection with nature (Respondent 0015); a (historical, as in Respondent 0021) relationship which waked up ideas or feelings of responsibility of taking care and protection (Respondents 0018, 0019, 0021, and 0022) or finally, concrete actions for the Baltic Sea (Respondent 0017).

Did the relationship include something that was non-negotiable? Picture 004 was very insightful. In it, a man pushes a wheelbarrow in the snow late at night. What is he doing and why? (Figure 11) The image was seen performing the helplessness of an individual to act on climate change. One does not know what tools to use and when. In the same picture, the person looks out at the sea, where frozen water and current have formed patterns (TFG). 


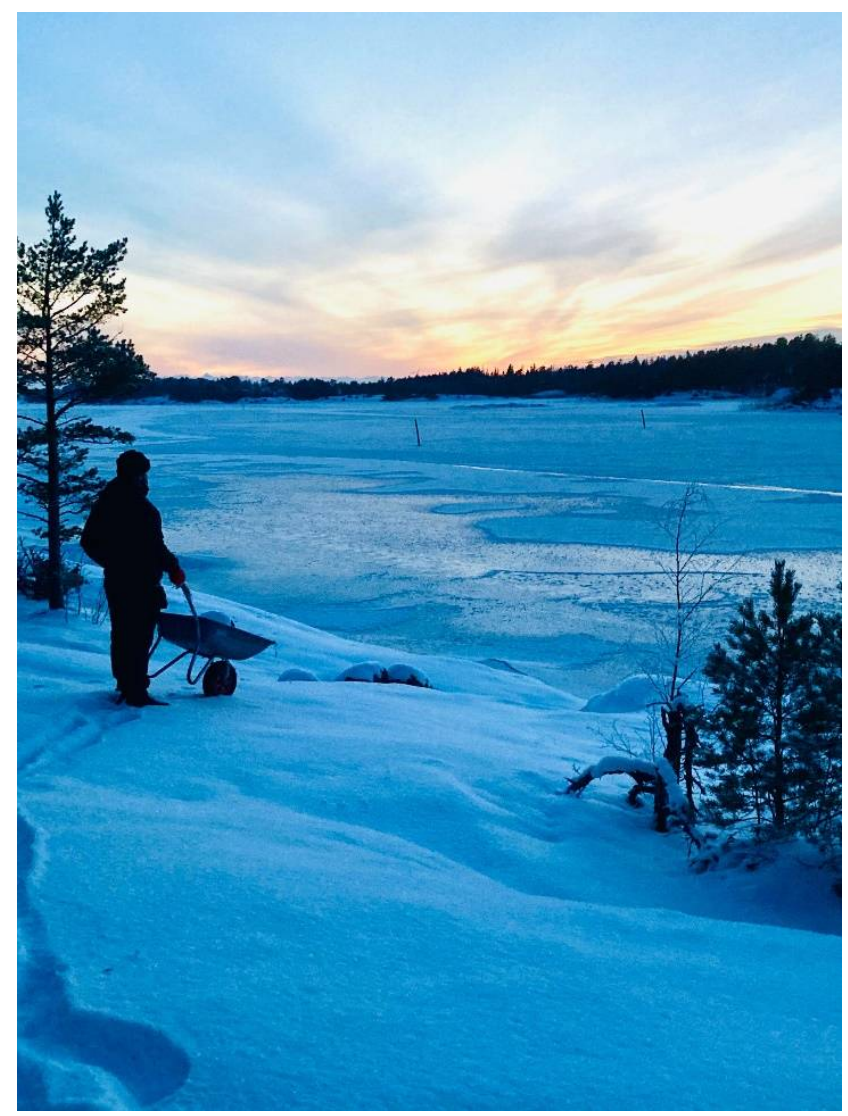

Figure 11. Visual performance of environmental change: What tools should we use in combating climate change?

\section{Discussions}

\subsection{Themes of Environmental Heritage}

These themes presented in the competition invitation were environmental heritage, change ("changes in flora and fauna, in climatic phenomena or in seasonal change"), agency ('all possible actors, both humans and non-humans' and "flora and fauna"), and actions, or broadly, the relationship with the Baltic Sea ("your ideas of all forms of actions and experiences, modes of doing and ways of being, or skills and knowledge related to coastal areas and archipelago of the Baltic Sea").

The data were coded, read with an eye to identify many different themes. Here these themes are presented as they emerged from the text and photos. It is interesting to note that $44 \%$ of the photos submitted contained a human being in some form interacting with the environment. The others were representations of the environment taken from the shore, looking out into the Baltic Sea. Together, the pictures and text appear as performances of the authors to the discussion about environmental heritage. They were answers to the invitation to contest and, at the same time, negotiations on these themes in relation to the Baltic Sea. In the analysis of texts, this also meant understanding individual words and concepts as actors of performances about environmental heritage. Following Bruno Latour's 56, ideas, they were tangible or intangible actants in the environment, but became actors in the network of meaning-making in the text $[51,56,61]$.

Almost all participants wrote about more than one of the themes presented in the competition invitation. The themes thus overlapped as well. In addition, several individual themes came to light from the writings. The contents of the writings seemed to be placed within these themes on a continuum between two extremes. Such continuum can also be seen in a way of presenting things, such as narrative descriptions on the one hand -among them one poem-and factual text on the other hand about the situation in the Baltic Sea 
from some point of view. The other extremes of the continuums were personal vs. general perspective or longing for stability vs. action for change.

\subsection{The Why of Environmental Heritage}

Reading through the data, it can be seen that people's perceptions of environmental heritage are influenced by what is important to them and what exists in their world. A clear theme emerging from the data was that personal connection is important in the articulation of environmental heritage, as they cited examples of environmental heritage that were personal and relevant to them. There are some aspects of the environmental heritage that were iconic signposts of a way of living, a beacon, as articulated here: "Built in 1858, the Härkmeri beacon on Torngrund, has guided many sailors home. As the years has passed by it no longer navigates anyone at sea, but it still remains a dear place for many local inhabitants. The white top made it easy to nickname - today the beacon is more known as 'Sockertoppen,' directly translated to 'the sugar top.' Through every season and weather the beacon stands facing the Bothnian Sea." (Respondent 009).

There was the articulation that heritage is important, and it connects generations as in the beacon above: "Once upon a time it was an important outpost. Today it is a landmark we cherish and during winter when the ocean has tucked away Torngrund in a blanket of ice, we long for the day that we once again can get a glimpse of the odd building. It has become a cultural heritage." (Respondent 009). The importance of heritage is linked to sustainability and the idea that we need to preserve it for future generations, "The Baltic Sea forms the basis for the environmental heritage of many, and for more to come" (Respondent 0013). Another participant notes that, "Heritage belongs to us, to nature, to the entire ecosystem, to all people. we are all in the same life cycle, closely connected to each other" (Respondent 0018).

Environmental heritage is seen as a legacy for future generations, and this helps to answer the question as to why it should be protected: "To conclude it is our duty to protect this environmental heritage, because it is something what we should save for next generations-it's birds, fishes, architecture, forests and so on. As the native American proverb goes "We don't inherit the earth from our ancestors, we borrow it from our children" and we have to do everything to minimalize that "loan" from our children, we should save this heritage at all costs because we owe it them" (Respondent 0022).

In addition to the need to the preservation goal, another theme emerging from the interest and why of environmental heritage is awareness raising and education about the way of life, "We are also part of the legacy, everything is inseparable. Our environmental awareness can help preserve and perpetuate heritage, and our contempt and perseverance may speed up its disappearance" (Respondent 0018). This idea was reiterated here, "[T]he Baltic Sea is the heritage of each one of us, and it's necessary for the future generations to have a place where to find themselves when they get a little bit lost" (Respondent 0016)

\subsection{Perceptions of Environmental Heritage and Change}

In the material the concept of environmental heritage is understood broadly as a way of living. The way of life consists of the human relationship to its environment and all its actors. It is described, for example, as recalling co-actors or acting with the sea. Actors may be creatures of nature, constructed objects, or, for example, intangible actors. They all participate in the process of environmental heritage. Environmental heritage itself is a functional and intentional performance. The performing environmental heritage can be an intangible reminiscence involving actors selected from the past or orienting in the present to the process of environmental heritage through action.

The writings and photographs that participated in the competition participated in the process of environmental heritage. The respondents also performed different waysfrom personal to general or from historical to biological perspective-of presenting what they found meaningful. Most often this was the environmental situation of the Baltic Sea. Emotions that are strongly involved in the process of environmental heritage are found in the continuum of longing for stability vs. action for change. These emotions 
do not need to be opposite. They all share the same goal. They are part of a human intangible environmental relationship that seeks to balance negative change they observe in the environment or merely express concern because of the environment. They signal an individual's experience in a global situation of change. Some respondents concern result in action, such as collecting trashes.

Environmental heritage is also a process of knowledge production. It begins in the observations, skills, and knowledge of, with, and in the environment as a meaning-making process of experience-based knowledge. It continues as a performance of environmental heritage as a discursive knowledge production with the given themes of competition invitation. In this process of environmental heritage, actors in the performances are chosen intentionally from the experience-based knowledge to be also in the future as part of the environmental heritage. They performance how individuals experience and observe global changes in local surroundings.

People living in the Baltic Sea region have become accustomed to the different variations of changes in the four seasons and different states of water and living with them. This information is important in other changes as well. It should be brought into an increasingly timely discussion with scientific knowledge- this is also a discussion the responders already had in their own texts in the competition. The local knowledge produced in the environmental heritage process is useful in adaptation and mitigation strategies. In climate change and other situations of the environmental change is therefore important to take into account this experience-based knowledge and develop different methods for achieving the discussion between, for example, experience-based knowledge and scientific knowledge.

\section{Conclusions}

In the core of the discourse about environmental heritage is the human relationship to her/his environment. The circulation of knowledge in some particular geographical area, such as the Baltic Sea region is, requires the use of multidisciplinary contextualization and various methods at the same time in one research. For example, theoretical concepts can be made visible outside of scientific discourse and at the same time question their usefulness representing different kind of knowledge. This article discusses one case study. However, one case study is not enough for a result or a theory; circulating concepts and ideas is an ongoing process and part of a discussion of heritage.

The description of the process is already part of the negotiation, in which people from outside the academy are invited as the actors of the heritage discourse. In their performances about heritage, they bring also non-human actors into the negotiation of sustainable heritage. Additionally, with this one case study, it is difficult to discern who the excluded groups are and as such, a recommendation for future research will be to investigate who is participating in environmental heritage.

In this study, participants received a concept, and guiding and inspiring themes to address it. Using these themes, the authors also analyzed and interpreted respondents' representations. The methodology was based on a guided task. One possible further study is the comparison and development of these methods for the recycling of experience-based knowledge. Since the sampling was small, this paper did not examine the environmental heritage reflecting on which country the author was from. This study did not capture sociodemographic data of respondents, so a limitation and avenue for further study is the analysis of perception of environmental heritage with generations and demographic status. Also, further studies can be extended so that the relationship to the sea also includes living in the coasts. These would all form themes for future study. Photos and texts handled nearly 100 per cent of the sea as experienced from the beach. Only two of the images were from the sea, a picture of an icebreaker and a wooden boat.

Based on the findings of this research, the following recommendations are made for incorporating environmental heritage into climate change dialogue:

- Engage the public into discussions on environmental heritage. As an exploratory study, this research has demonstrated that the public is interested to share their experiences 
of environmental change. This knowledge can be useful in decision-making with regards to adaptation and mitigation actions.

- Frame climate change activities under the lens of environmental heritage: This study has shown that the public prefers to live and interact with the environment. This can be utilized in the framing of climate change actions to engage the public toward actions such as carbon zero goals etc. Recreational activities and participating in cultural events can motivate greater environmental stewardship.

- Harness the public's broad view of environmental heritage: This study has demonstrated that the public understands environmental heritage as relating to locations, things, fauna, flora, emotions, legacy, etc. This can be used in policy documents for action relating to heritage and climate change.

- Utilize storytelling to promote connection with the environment: This study shows that activities that promote public connection with the environment and utilize creative storytelling are like to be popular and effective.

- Create synergies between disciplines: Environmental heritage has been framed in terms of legacy for future generations. This has coherence with the concepts of sustainability and resilience. As such, more interdisciplinary studies are needed to foster greater synergies between disciplines and to holistically approach environmental problems such as climate change.

- Explore the economic benefits of environmental heritage further: One of the themes brought out by this study included the linking of economics and heritage. This could be studied further, with the aim of strengthening will through the use of economic figures that could stimulate action and investment toward adaptation and mitigation actions for dealing with climate change.

Author Contributions: This article was conceptualized by S.J. and J.K. and outline drafted by S.J. Literature review, methods, and results and discussion written by both J.K. and S.J. Coding and data analysis done by both S.J. and J.K. Both authors have read and agreed to the published version of the manuscript.

Funding: This research received academy of Finland SeaHer funding, grant number 315715". The authors also wish to acknowledge support from the "Sea" profiling area of Åbo Akademi University.

Institutional Review Board Statement: Not applicable.

Informed Consent Statement: Not applicable.

Data Availability Statement: All data is stored by the SeaHer project database. SeaHer-blog 2021. (https://blogs2.abo.fi/seaher/2021/05/25/the-seaher-photo-competition-winners_-the-ju dging-process-and-the-winning-submissions / accessed on 20 June 2021). Submissions 0001-00023 ... Archived in the archives of the authors of this article and SeaHer. Åbo Akademi University, Abo. TFG Transcription of the recording of the negotiation of the focus group 10 May 2021 in Zoom. Archived in the archives of the authors of this article and SeaHer. Åbo Akademi University, Åbo.

Acknowledgments: The authors are grateful for being part of the SeaHer project and thank all team members for the rich discussions.

Conflicts of Interest: The authors declare no conflict of interest.

\section{References}

1. HELCOM. The Helsinki Commission Website. 2021. Available online: https://helcom.fi/baltic-sea-trends/data-maps/database S/ (accessed on 9 April 2021).

2. Jetoo, S.; Krantzberg, G. Early Lessons of COVID-19 for Governance of the North American Great Lakes and the Baltic Sea. World 2020, 1, 318-329. [CrossRef]

3. Reusch, T.B.H.; Dierking, J.; Andersson, H.C.; Bonsdorff, E.; Carstensen, J.; Casini, M.; Czajkowski, M.; Hasler, B.; Hinsby, K.; Hyytiäinen, K.; et al. The Baltic Sea as a time machine for the future coastal ocean. Sci. Adv. 2018, 4, eaar8195. [CrossRef] [PubMed]

4. Belkin, I.M. Rapid warming of Large Marine Ecosystems. Prog. Oceanogr. 2009, 81, 207-213. [CrossRef] 
5. Merkouriadi, I.; Leppäranta, M. Long-term analysis of hydrography and sea-ice data in Tvärminne, Gulf of Finland, Baltic Sea. Clim. Chang. 2014, 124, 849-859. [CrossRef]

6. Tynkkynen, N.; Schönach, P.; Pihlajamäki, M.; Nechiporuk, D. The Governance of the Mitigation of the Baltic Sea Eutrophication: Exploring the Challenges of the Formal Governing System. Ambio 2014, 43, 105-114. [CrossRef]

7. Robin, L. Global Ideas in Local Places: The Humanities in Environmental Management. Environ. Humanit. 2012, 1, 69-84. [CrossRef]

8. Jetoo, S. Multi-level governance innovations of the Baltic Sea and the North American Great Lakes: New actors and their roles in building adaptive capacity for eutrophication governance. Mar. Policy 2018, 98, 237-245. [CrossRef]

9. Greschke, H.; Tischler, J. Grounding Global Climate Change. Contributions from the Social and Cultural Sciences; Springer: Dordrecht, The Netherlands, 2014.

10. Jetoo, S.; Tynkkynen, N.; Törnroos, A.; Sojquist, C.; Helstrom, M.; Joas, M. Climate change and the governance of the Baltic Sea environment. J. Balt. Stud. 2021. Accepted manuscript in process.

11. Warde, P.; Coates, P.; Moon, D. Local places, global processes: In search of the environment. In Local Places, Global Processes. Histories of Environmental Change in Britain and beyond; Warde, P., Coates, P., Moon, D., Eds.; Oxbow Books: Oxford, UK, 2016; pp. $1-16$.

12. Kirby, D.; Hinkkanen, M.-L. The Baltic and the North Seas; Routledge: London, UK, 2000.

13. Palsson, G.; Szerszynski, B.; Sörlin, S.; Marks, J.; Avril, B.; Crumley, C.; Hackmann, H.; Holm, P.; Ingram, J.; Kirman, A.; et al. Reconceptualizing the 'Anthropos' in the Anthropocene: Integrating the social sciences and humanities in global environmental change research. Environ. Sci. Policy 2013, 28, 3-13. [CrossRef]

14. Burke, P. What Is the History of Knowledge? John Wiley \& Sons: Cambridge, UK, 2016.

15. SeaHer. Living with the Baltic Sea in a Changing Climate. SeaHer Website and Blog. 2021. Available online: https://blogs2.abo.f i/seaher/2021/05/25/the-seaher-photo-competition-winners_-the-judging-process-and-the-winning-submissions / (accessed on 20 June 2021).

16. Röschel, L.; Graef, F.; Dietrich, O.; Schäfer, M.P.; Haase, D. Individual local farmers' perceptions of environmental change in Tanzania. Water 2018, 10, 525. [CrossRef]

17. Weber, E.U. Experience-based and description-based perceptions of long-term risk: Why global warming does not scare us (yet). Clim. Chang. 2006, 77, 103-120. [CrossRef]

18. Ayeni, A.O.; Olorunfemi, F.B. Reflections on environmental security, indigenous knowledge and the implications for sustainable development in Nigeria. J. Res. Natl. Dev. 2014, 12, 46-57.

19. Leiserowitz, A. International public opinion, perception, and understanding of global climate change. Hum. Dev. Rep. 2007, 2008, $1-40$.

20. UNESCO. Perception of Environmental Quality; UNESCO: Paris, France, 1973; p. 76.

21. IPCC. Climate Change and Land: An IPCC Special Report on Climate Change, Desertification, Land Degradation, Sustainable Land Management, Food Security, and Greenhouse Gas Fluxes in Terrestrial Ecosystems; Shukla, P.R., Skea, J., Calvo Buendia, E., MassonDelmotte, V., Pörtner, H.O., Roberts, D.C., Zhai, P., Slade, R., Connors, S., van Diemen, R., et al., Eds.; 2019; In press.

22. Maddison, D. The Perception of and Adaptation to Climate Change in Africa; The World Bank: Washington, DC, USA, 2007.

23. Boyd, D.; Crawford, K. Critical questions for big data: Provocations for a cultural, technological, and scholarly phenomenon. Inf. Commun. Soc. 2012, 15, 662-679. [CrossRef]

24. Eduful, M.; Shively, D. Perceptions of urban land use and degradation of water bodies in Kumasi, Ghana. Habitat Int. 2015, 50, 206-213. [CrossRef]

25. Thornton, A. Public Attitudes and Behaviours towards the Environment-Tracker Survey: A Eeport to the Department for Environment. Food and Rural Affairs; DEFRA: London, UK, 2009.

26. Lorenzoni, I.; Pidgeon, N.F. Public views on climate change: European and USA perspectives. Clim. Chang. 2006, 77, 73-95. [CrossRef]

27. Pidcock, R. Principles for effective communication and public engagement on climate change. In A Handbook for IPCC Authors; Corner, A., Shaw, C., Clarke, J., Eds.; Climate Outreach: Oxford, UK, 2018.

28. Tippett, J.; Searle, B.; Pahl-Wostl, C.; Rees, Y. Social learning in public participation in river basin management-Early findings from HarmoniCOP European case studies. Environ. Sci. Policy 2005, 8, 287-299. [CrossRef]

29. Sheppard, S.R. Bridging the sustainability gap with landscape visualisation in community visioning hubs. Integr. Assess. 2006, 6 , 79-108.

30. Altinay, Z.; Williams, N. Visuals as a method of coastal environmental communication. Ocean. Coast. Manag. $2019,178,104809$. [CrossRef]

31. Kahneman, D. Thinking, Fast and Slow; Macmillan: New York, NY, USA, 2011.

32. DiFrancesco, D.; Young, N. Seeing climate change: The visual construction of global warming in Canadian national print media. Cult. Geogr. 2011, 18, 517-536. [CrossRef]

33. Brönnimann, S. Picturing climate change. Clim. Res. 2002, 22, 87-95. [CrossRef]

34. Taylor, A.L.; Dessai, S.; de Bruin, W.B. Public perception of climate risk and adaptation in the UK: A review of the literature. Clim. Risk Manag. 2014, 4, 1-16. [CrossRef] 
35. Wang, S.; Corner, A.; Chapman, D.; Markowitz, E. Public engagement with climate imagery in a changing digital landscape. Clim. Chang. 2018, 9, e509. [CrossRef]

36. Oxford Dictionary. Heritage. 2021. Available online: https://www.oxfordlearnersdictionaries.com/us/definition/english/herita ge (accessed on 29 March 2021).

37. UNESCO. UNESCO Marine World Heritage: Custodians of the Globe's Blue Carbon Assets; UNESCO: Paris, France, 2020.

38. UNESCO. High Coast/Kvarken Archipelago. UNESCO World Heritage Site Website. 2021. Available online: https://whc.unesco .org/en/publications/ (accessed on 5 April 2021).

39. Smith, L. Uses of Heritage; Routledge: London, UK, 2006.

40. Smith, L. The 'doing' of heritage: Heritage as performance. In Performing Heritage: Research, Practice and Innovation in Museum Theatre and Live Interpretation; Jackson, A., Kidd, J., Eds.; Manchester University Press: Manchester, UK, 2011 ; pp. 69-81.

41. Guttormsen, T.S.; Swensen, G. Introduction: Heritage, democracy and the public: Nordic approaches. In Heritage, Democracy, and the Public; Guttormsen, T.S., Swensen, G., Eds.; Ashgate: Farnham, UK, 2016; pp. 1-10.

42. Blake, J. On Defining the Cultural Heritage. Int. Comp. Law Q. 2000, 49, 61-85. [CrossRef]

43. Silverman, H.; Ruggles, D.F. Introduction. In Cultural Heritage and Human Rights; Silverman, H., Ruggles, D.F., Eds.; Springer: New York, NY, USA, 2007; pp. 3-29.

44. Siivonen, K. Intangible cultural heritage will revolutionise the future. In Wohin Geht die Reise? Eggmann, S., Kolbe, S., Winkler, J., Eds.; 2019; pp. 93-97, Akroama Editions. Available online: https://www.geruchderzeit.org/siivonen (accessed on 18 March 2021).

45. Van Donkersgoed, J.; Brown, J. Intangible culture as the prime asset of a cultural landscape and seascape: A case study of the Banda Islands, Indonesia. In Research Handbook on Contemporary Intangible Cultural Heritage: Law and Heritage; Waelde, C., Cummings, C., Pavis, M., Enright, H., Eds.; Edward Elgar Publishing: Cheltenham, UK, 2018; pp. 363-378.

46. Phillips, A. Landscape as a Meeting Ground. Category V Protected Landscapes/Seascapes and World Heritage Cultural Landscapes. In The Protected Landscape Approach: Linking Nature, Culture and Community; Brown, J., Mitchell, N., Beresford, M., Eds.; IUNC-The World Conservation Union: Gland, Switzerland, 2005; pp. 19-35. Available online: https://portals.iucn.org/lib rary/sites/library/files/documents/2005--006.pdf (accessed on 20 March 2021).

47. UNESCO. Convention for the Safeguarding of the Intangible Cultural Heritage. 2003. Available online: http:/ / portal.unesco.or g/en/ev.php-URL_ID=17716\&URL_DO=DO_TOPIC\&URL_SECTION=201.html (accessed on 28 March 2021).

48. Dorfman, E. Intangible Natural Heritage: New Perspectives on Natural Objects; Routledge: Abingdon, UK, 2012.

49. Warde, P. The Environment. In Local Places, Global Processes. Histories of Environmental Change in Britain and Beyond; Warde, P., Coates, P., Moon, D., Eds.; Oxbow Books: Oxford, UK, 2016; pp. 32-46.

50. Laurén, K. Suo-Sisulla Ja Sydämellä. Suomalaisten Suokokemukset Ja-Kertomukset Kulttuurisen Luontosuhteen Ilmentäjinä; Finnish Litterature Society: Helsinki, Finland, 2006.

51. Kouri, J. Vesi Kuljettaa Ä̈̈ntä. Autoetnografinen Tutkimus Lypyrtin Kylän Historian Tuottamisesta; The University of Turku: Turku, Finland, 2017.

52. Ingold, T. The Perception of the Environment: Essays on Livelihood, Dwelling and Skill; Routledge: London, UK, 2000.

53. Polanyi, M.; Prosch, H. Meaning; The University of Chicago Press: Chicago, IL, USA, 1975.

54. Polanyi, M. The Tacit Dimension; The University of Chicago Press: Chicago, IL, USA, 1966.

55. Frykman, J.; Gilje, N. Being there. An introduction. In Being There: New Perspectives on Phenomenology and the Analysis of Culture; Frykman, J., Gilje, N., Eds.; Nordic Academic Press: Lund, Sweden, 2003; pp. 7-51.

56. Latour, B. Reassembling the Social: Introduction to the Actor-Network-Theory; Oxford University Press: Oxford, UK, 2005.

57. Lund, K.A.; Benediktsson, K. Introduction: Starting a conversation with landscape. In Conversations with Landscape; Benediktsson, K., Lund, K.A., Eds.; Ashgate: Farnham, UK, 2010; pp. 1-12.

58. Vannini, P. Introduction. In Material Culture and Technology in Everyday Life. Ethnographic Approaches; Vannini, P., Ed.; Peter Lang: New York, NY, USA, 2009; pp. 3-12.

59. Massey, D. Spatial Divisions of Labour: Social Structures and the Geography of Production. Critical Human Geography; Macmillan: Basingstoke, UK, 1985.

60. Siikala, A.-L. Toisiinsa virtaavat maailmat. In Kaukaa Haettua-Kirjoituksia Antropologisesta Kenttätyöstä; Viljanen, A.M., Lahti, M., Eds.; Finnish Anthropological Society: Helsinki, Finland, 1997; pp. 20-34.

61. Kouri, J. Toimijat esiin. Tekstualisaation malli etnografisessa tutkimuksessa. Uskonnontutkija 2017, 6. Available online: https: / /journal.fi/uskonnontutkija / article/view / 68865 (accessed on 20 June 2021).

62. Polkinghorne, D.E. Narrative configuration in qualitative analysis. Int. J. Qual. Stud. Educ. 1995, 8, 5-23. [CrossRef]

63. Gustafson, P. Meanings of place: Everyday experience and theoretical conceptualizations. J. Environ. Psychol. 2001, 21, 5-16. [CrossRef]

64. Miles, M.B.; Huberman, A.M. Qualitative Data Analysis: An Expanded Sourcebook; Sage: Thousand Oaks, CA, USA, 1994.

65. Knoblauch, H.; Baer, A.; Laurier, E.; Petschke, S.; Schnettler, B. Visual analysis. New developments in the interpretative analysis of video and photography. Forum Qual. Soz. Forum Qual. Soc. Res. 2008, 9. [CrossRef]

66. Christmann, G.B. The power of photographs of buildings in the Dresden urban discourse. Towards a visual discourse analysis. Forum Qual. Soz. Forum Qual. Soc. Res. 2008, 9. [CrossRef]

67. Frith, H.; Riley, S.; Archer, L.; Gleeson, K. Editorial. Qual. Res. Psychol. 2005, 2, 187-198. [CrossRef] 
68. Sheppard, S.R. Landscape visualisation and climate change: The potential for influencing perceptions and behaviour. Environ. Sci. Policy 2005, 8, 637-654. [CrossRef]

69. Sheppard, S.R.; Meitner, M. Using multi-criteria analysis and visualisation for sustainable forest management planning with stakeholder groups. For. Ecol. Manag. 2005, 207, 171-187. [CrossRef]

70. Nicholson-Cole, S.A. Representing climate change futures: A critique on the use of images for visual communication. Comput. Environ. Urban Syst. 2005, 29, 255-273. [CrossRef]

71. Lorenzoni, I.; Langford, I.H. Climate Change Now and in the Future: A Mixed Methodological Study of Public Perceptions in Norwich (UK); Centre for Social and Economic Research on the Global Environment: Norwich, UK, 2001.

72. Duan, R.; Takahashi, B.; Zwickle, A. How Effective Are Concrete and Abstract Climate Change Images? The Moderating Role of Construal Level in Climate Change Visual Communication. Sci. Commun. 2021, 43, 358-387. [CrossRef]

73. Wong-Parodi, G.; Feygina, I. Engaging People on Climate Change: The Role of Emotional Responses. Environ. Commun. 2021, 15, 571-593.

74. Kouri, J.; Siivonen, K. Tulevaisuusperintö ihmisen kestävän merellisen luontosuhteen perustana. In Muutoksen Tyrskyt ja Kotirannan Mainingit-Kulttuurisia Näkökulmia Merentutkimukseen; Kouri, J., Räsänen, T., Tynkkynen, N., Eds.; Finnish Litterature Society: Helsinki, Finland, 2020; pp. 76-100. 